УДК 94 (477.7) «1941/1943»

DOI: https://doi.org/10.33782/eminak2020.3(31).443

\title{
БОЛГАРСЬКІ СЕЛА ПІВНІЧНОГО ПРИАЗОВ'Я У 1941-1943 РОКАХ: НІМЕЦЬКА ОКУПАЦІЯ В ЕТНІЧНОМУ ВИМІРІ
}

\author{
Марія Пачева \\ Запорізький національний університет (Запоріжжя, Україна) \\ e-mail: pacheva.mariya.18@gmail.com \\ ORCID: https://orcid.org/0000-0003-3635-4508
}

Аналізу піддано політику окупаційної німецької влади стосовно жителів болгарських сіл Північного Приазов'я. Виявлено, що й у рідному селі, і на примусових роботах у Німеччині, місцеві болгари не мали помітних преференцій за національною ознакою порівняно $з$ іншими жителями регіону. Єдина обставина, що вирізняла болгар, - можливість встановлення зв'язку з історичною батьківщиною з метою пошуку захисту та допомоги. Щоправда, використання цієї можливості не набуло великого поширення. Одним з їі виявів стала спроба репатріації деякої кількості таврійських болгар на історичну батьківщину, що завершилася їх примусовим поверненням до СРСР у 1945 .

Ключові слова: таврійські болгари, Північне Приазов'я, Друга світова війна, репатріація

Друга світова війна залишила глибокий слід у суспільній свідомості українського народу, а отже воєнна тематика продовжує перебувати у центрі громадської уваги, нерідко кристалізуючи діаметрально протилежні погляди. Через це вже багато десятиліть зберігається суспільна значимість звернення істориків до цього трагічного періоду. В останні десятиліття, зокрема, увагу дослідників привертають не лише перебіг подій на фронті, а й становище на окупованих територіях. Зважаючи на багатонаціональний склад населення України, серед актуальних напрямків вивчення цієї сторінки вітчизняної історії є дослідження буття мирних жителів під час німецької окупації в етнічному розрізі.

Метою нашої наукової розвідки є виявлення особливостей становища болгарської етнічної меншини в умовах німецького окупаційного режиму. Іншими словами, ставимо за мету визначити, чи вплинув факт союзницького до Німеччини статусу Болгарії у Другій світовій війні на становище болгарського населення півдня України. Територіальні рамки дослідження локалізуємо північно-приазовським регіоном, оскільки саме там розташований найбільший ареал компактного поселення болгар на теренах, включених до Рейхскомісаріату Україна (болгарські села Бессарабії та правобережжя Південного Бугу, як відомо, потрапили до румунської зони окупації).

Хоча у вітчизняній історіографії є немало праць, присвячених вивченню становища сільського населення України у період Другої світової війни, його аналізу у розрізі окремих етнічних груп не приділялося достатньо уваги. У тому числі $\epsilon$ немало «білих плям» у висвітленні буття болгар Північного Приазов'я у роки окупації. Деякі аспекти досліджуваної теми були відображені у статтях Ю.0.Іріоглу1,

\footnotetext{
${ }^{1}$ Іріоглу Ю. Друга світова війна в усних історіях болгар Північного Приазов'я. Българите в Северното Причерноморие. Изследвания и материали. Т. 10. Одеса-Велико Търново, 2009. С. 179-186.
} 
В.І. Мільчева², Л.Ф. Ноздріної3, у краєзнавчих дослідженнях з історії окремих болгарських сіл Таврії (праці В.Д. Добрєва ${ }^{4}$ та Л.В. Жавжарова5). Проте ця тема потребує подальшого поглибленого вивчення.

Джерельна база нашого дослідження складається з комплексу опублікованих та неопублікованих джерел. До опублікованих джерел належать документи, включені до збірників «Запорожская область в годы Великой Отечественной войны (1941-1945)»6 та «Запорізький архів. Народна війна. 1941-1944. Антифашистський рух Опору на території Запорізької області»7, а також спогади болгар Північного Приазов'я, вміщені у 6 томі книги «Усна історія Степової України»8 та у збірнику «Таврійські історії»9.

До неопублікованих джерел належать архівні матеріали, які зберігаються у Державному архіві Запорізької області 10 та Галузевому державному архіві Служби безпеки України (м. Запоріжжя) ${ }^{11}$, а також усні наративи жителів болгарських сіл Райнівки (Приморського району) ${ }^{12}$ та Ботієве (Приазовського району) ${ }^{13}$ зібрані у

2 Мільчев В.І. Між двох диктатур: Першоджерела про витоки переселенської активності болгарсь-
кого населення Таврії в роки Другої Світової війни. Наукові праці історичного факультету Запо-
різького національного університету. Запоріжжя, 2016. Вип. 46. С. 226-243
${ }^{3}$ Ноздрина Л.Ф. Болгары Приазовья - участники исторических событий ХХ века. Матеріали між-
народної наукової конференції «IV Приазовський болгаристичний семінар». Велико Тирново-
Мелітополь: Видавництво Мелітопольського державного педагогічного університету імені Бог-
дана Хмельницького, 2012. С. $90-100$.
4 Добрев В.Д. Чушмелій. Мелітополь-Велико Тирново, 2009. 310 с.
5 Жавжаров Л.В. Райновка: история и судьбы. Мелитополь: Издательский дом МГТ, 2011. 205 с.
6 Запорожская область в годы Великой Отечестенной войны (1941-1945). Сборник документов.
Запорожье: Запорожское книжно-газетное издательство, 1959. 362 с.
7 Запорізький архів. Народна війна. $1941-1944$. Антифашистсьий рух Опору на території Запорі-
зької області: Збірник документів і матеріалів / авт.-упоряд:: В.О. Бондар, О.Г. Величко, I.В. Козлова. Запоріжжя: Прем'єр, 2005. 560 с.

8 Усна історія Степової України. Запоріжжя: АА Тандем, 2009. Т. 6. 464 с.

9 Паскалов Л. Таврійські історії. Оповідання болгар Північного Приазов'я. Збірка газетних публікацій. Мелітополь: ФОП Силаєва О.В., 2016. 384 с.

10 Акти про принесений збиток громадянам німецькими військами. (Виконавчий комітет Радолівської Сільської ради депутатів трудящих с. Радолівка, Приморського району, Запорізької області. 1944-1954 рр.). Державний архів Запорізької області. Ф. Р-4667. Оп. 1. Спр. 4; Списки і акти громадян, яким нанесені збитки німцями. (Виконавчий комітет Петрівської сільської Ради депутатів трудящих. Село Петрівка Приморського району, Запорізької області). Державний архів Запорізької області. Ф. Р-3518. Оп. 1. Спр. 1.

11 Вирок військового трибуналу 37-ї армії від 6-7 липня 1945 р. у справі з обвинувачення громадян СРСР Клименко Олени Олександрівни, Мільчева Петра Дмитровича, Мільчевського Петра Андрійовича, Терзієва Івана Дмитровича, Буюклійського Дмитра Олексійовича, Мільчевського Івана Георгійовича. Галузевий державний архів СБ Украӥни, м. Запоріжжя Справа № 19886-П. Т. 1. Арк. 291-297

12 Фонограма спогадів Малєва Івана Андрійовича (1937 р.н.), записаних у селі Райнівка Приморського району Запорізької області у 2018 р.; Фонограма спогадів Узунова Георгія Степановича (1937 р.н.), записаних у селі Райнівка Приморського району Запорізької області у 2018 р.; Фонограма спогадів Чернишева Миколи Івановича (1939 р.н.), записаних у селі Райнівка Приморського району Запорізької області у 2018 р.; Фонограма спогадів Чернишевої Валентини Аркадіївни (1928 р.н.), записаних у селі Райнівка Приморського району Запорізької області у 2018 р.

13 Фонограма спогадів Волчанової Марії Федорівни (1924 р.н.), записаних у селі Ботієве Приазовського району Запорізької області 03.09.2002 р.; Фонограма спогадів Іванової Стефаниди Петрівни (1919 р.н.), записаних у селі Ботієве Приазовського району Запорізької області 05.09.2002 p.; Фонограма спогадів Кулової Антоніни Терентіївни (1925 р.н.), записаних у селі Ботієве Приазовського району Запорізької області 06.09.2002 р.; Фонограма спогадів Кулової Марії Михайлівни (1919 р.н.), записаних у селі Ботієве Приазовського району Запорізької області 02.09.2002 р.; Фонограма спогадів Орєшкової Надії Федорівни (1923 р.н.), записаних у селі Ботієве Приазовського 
ході наукових експедицій.

Болгарські села Північного Приазов'я опинилися під окупацією восени 1941 p. Першими до зони наступу німецьких військ потрапили села, що розташовані на правобережжі р. Молочної та Молочного лиману. Це сталося 17 вересня під час боїв на підступах до Мелітополя ${ }^{4}$. Основна ж маса болгарських сіл регіону була окупована на початку жовтня у результаті одночасного наступу німецької 1-ї танкової армії з району Оріхова та моторизованих частин 11-ї армії з району Мелітополя, які 7 жовтня з'єдналися на північ від Осипенко (Бердянськ). Південні райони області, в яких розташовані болгарські села, разом з частиною Херсонської області та Кримом, увійшли до складу округу «Таврія» Рейхскомісаріату «Україна» 15.

Дослідники справедливо відзначають, що болгари, як і решта національних меншин «західного» походження, сприймалися владою як «п'ята колона» й у передвоєнні роки найбільше постраждали від репресій, а отже не мали особливої мотивації активно підтримувати радянську владу у війні із Німеччиною16. 3 іншого боку, попри підозрілість більшовицької влади, вони також не мали мотивів підтримувати ворога.

У наш час історики подолали притаманний радянській історіографії спрощений погляд на настрої населення України під час окупації. Утверджується розуміння співіснування різних стратегій поведінки. Незначне коло осіб, як правило, ображених радянською владою, ставали на шлях свідомої співпраці з окупантами. Представники прошарку, який можна охарактеризувати як радянських активістів, обирали активний спротив. Щоправда, в умовах степової України можливості для цього були дуже обмежені. Але серед переважної більшості українських селян, на думку дослідників, «взяли гору настрої вичікування, пасивне сприйняття наявної ситуації», «на перший план вийшла проблема виживання»17.

Прихід окупантів супроводжувався поверненням до деяких сплюндрованих радянською владою цінностей, важливих для болгарських громад Північного Приазов'я, які, за спостереженням Ю. Іріоглу, на той момент «залишалися анклавами традиційного аграрного суспільства»18. Одна з таких цінностей лежала у релігійній площині. Після майже двох десятиліть атеїстичного тиску у болгарських селах регіону почали відкриватися церкви. На окупованій території (у тому числі й у багатьох болгарських селах) відновили свою діяльність релігійні громади, відкривалися храми та молитовні будинки, проводилися богослужіння ${ }^{19}$. Наприклад, у нашому розпорядженні є спогади жителів с. Райнівка, що в їхньому селі знову відкрилася церква, приміщення якої у часи сталінської модернізації було облаштовано під сільський клуб. Службу відправляв румунський священик ${ }^{20}$. За словами респонде-

району Запорізької області 03.09.2002 р.; Фонограма спогадів Христова Івана Степановича (1915 р.н.), записаних у селі Ботієве Приазовського району Запорізької області 03.09.2002 p.

14 Сборник боевых документов Великой Отечественной войны. Вып. 40. Москва: Воениздат, 1960.

15 Шайкан В. Повсякдення українців у роки німецької окупації. 1941-1944. Київ, 2010. С. 9; Запорізький рахунок Великій війні. 1939-1945 / В.М. Мороко та ін., за заг. ред. Ф.Г. Турченка. Запоріжжя: Просвіта, 2013. С. 138.

16 Запорізький рахунок Великій війні... С. 54.

17 Ibid. C. 54-58.

18 Іріоглу Ю. Вказ. пр. С. 180.

19 Запорізький рахунок Великій війні... С. 229-230.

20 Жавжаров Л.В. Райновка: история и судьбы. Мелитополь: Издательский дом МГТ, 2011. С. 37; Фонограма спогадів Узунова Георгія Степановича (1937 р.н.), записаних у селі Райнівка Приморського району Запорізької області у 2018 p. 
нтів, працювала церква також і у Преславі21.

У селян було сподівання про повернення до традиційної, доколгоспної форми обробітку землі. Ці ілюзї̈ підігрівалися пропагандою. Як згадує одна з респонденток: «Немцы, когда заходили, тут в селе замерли аж все! Пускаеть, самолет идет, пускает афишки, наклейки, и так афишки отут во дворе афишки падают! ...А там написано на немецком и на русском, что бросайте колхоз, мы вам поможем, индивидуально будете работать, кто-то читал там, рассказывал! Землю вам дадим!» (Стояновська P.O., 1912 р.н.) ${ }^{22}$.

Проте, ці ілюзії не виправдалися. У болгарських селах, як і в інших селах Запорізького краю, окупанти не поспішали ліквідувати колгоспну систему, адже вона була добре пристосована для викачування ресурсів із села23. У наказі начальника Ногайського району М. Полункіна старості с. Інзовка П. Мільчеву, датованому 10 січня 1942 р., розподіл колгоспної землі та худоби суворо заборонявся, а те колгоспне майно, яке селяни вже встигли забрати собі, вимагалося негайно повернути. Колгоспи було перейменовано на «загальні двори», а радгоспи - на «земські двори» 24.

Про збереження колгоспної системи у болгарських селах Приазов’я під час окупації збереглося чимало свідчень. Низка жителів с. Ботієве, у тому числі А.Т. Кулова (1925 р.н.) ${ }^{25}$, Н.Ф. Орєшкова (1923 р.н.)26, М.П. Тодоров (1920 р.н.) ${ }^{27}$, І.С.Христов (1915 р.н.) ${ }^{28}$, стверджують, що під час окупації продовжували працювати у колгоспі.

Існували й неофіційні форми організації землі, відомі як системи «десяток» або «десятихаток». Ландвірти ${ }^{29}$ дозволяли ланці, що часто складалася з членів однієї родини, обробляти лише окрему, «свою», ділянку-десятину, причому кожна така ланка мала власний реманент і тяглову силу. Колективною справою залишалися лише жнива ${ }^{30}$.

Про існування «десяток» згадують, наприклад, жителі болгарського села Преслава: «Были колхозы и мы их начали делить (...) нашим родителям давали на десять дворов, одна лошадь, это немцы уже давали такое, чтоб обрабатывать там землю (...) Дали тебе лошадь, коси, сей, сдавай зерно» (0.0.Кочкова, 1923 р.н.) ${ }^{31}$;

\footnotetext{
21 Усна історія Степової України. Запоріжжя: АА Тандем, 2009. Т. 6. С. 99.

22 Усна історія Степової України... С. 40-41.

23 Мільчев B.I. Між двох диктатур: Першоджерела про витоки переселенської активності болгарського населення Таврії в роки Другої Світової війни. Наукові праці історичного факультету Запорізького національного університету. Запоріжжя, 2016. Вип. 46. С. 227.

${ }^{24}$ Наказ начальника Ногайського району М. Полункіна старості с. Інзовка П. Мільчеву відносно заходів, які необхідно вжити. Державний архів Запорізької області. Ф. Р-3051. Оп. 1. Спр. 2. Арк. 108.

25 Фонограма спогадів Кулової Антоніни Терентіївни (1925 р.н.), записаних у селі Ботієве Приазовського району Запорізької області 06.09.2002 p.

26 Фонограма спогадів Орєшкової Надії Федорівни (1923 р.н.), записаних у селі Ботієве Приазовського району Запорізької області 03.09.2002 p.

27 Фонограма спогадів Тодорова Миколи Петровича (1920 р.н.), записаних у селі Ботієве Приазовського району Запорізької області 02.09.2002 p.

28 Фонограма спогадів Христова Івана Степановича (1915 р.н.), записаних у селі Ботієве Приазовського району Запорізької області 03.09.2002 p.

29 Ландвірт (нім. сільський господар) - сільськогосподарські керівники з поліцейськими правами у Рейхскомісаріаті Україна, які займалися землевпорядкуванням та організацією сільськогосподарських робіт і стали важливою ланкою окупаційного економічного апарату. - Прим. ред.

30 Беркгоф Карел. Жнива розпачу. Життя і смерть в Україні під нацистською владою. Київ: Критика, 2011. С. 132.

31 Усна історія Степової України... С. 130.
} 
«Когда пришли румыны, стали организовывать как... Десятки, вместо колхозов. От десятки и там несколько человек с коровами» (В.Г. Лякішева, 1925 р.н.) ${ }^{32}$.

Німецька влада, як і радянська, вимагала значних поставок сільськогосподарської продукції, крім того, селян обклали продовольчими та грошовими податками ${ }^{33}$. Проте, на думку окремих дослідників, у цілому рівень життя селян області під час окупації навіть дещо покращився, оскільки частину вирощеної продукції селянам вдавалося залишати собі, приховавши їі від німців (що рідше вдавалося за радянської влади) ${ }^{34}$. Про деяке покращення рівня життя під час окупації згадують респонденти у своїх інтерв'ю, наприклад житель с. Райнівка I.А. Малєв (1937 р.н.) ${ }^{35}$.

Однак все ж ми можемо констатувати, що сподівання селян на повну ліквідацію колгоспної системи не виправдалися. Так само не виправдалися й сподівання розкуркулених селян на повернення власного майна - згідно з розпорядженням орткомендатури Бердянська від 18 квітня 1942 р. майно, конфісковане більшовиками, заборонялося повертати колишнім власникам 36.

Місцеві жителі для нацистської Німеччини залишалися «людьми другого сорту», що виражалося, зокрема, у частому застосуванні до них фізичних покарань ${ }^{37 .}$ Проте, як стверджує Ю.О. Іріоглу на основі спогадів респондентів, ставлення представників окупаційних військ до жителів болгарських сіл, у більшості випадків, не вирізнялося особливою жорстокістю ${ }^{38}$.

Низка респондентів, у тому числі Р.О.Стояновська (1912 р.н.) ${ }^{39}$, О.Ф. Малєв (1922 р.н.) ${ }^{40}$, А.І. Фуклєв (1922 р.н.) ${ }^{41}$, З.А. Фуклєва (1929 р.н.) ${ }^{42}$, Н.Ф. Орєшкова (1923 р.н., с. Ботієве) ${ }^{43}$ пригадують випадки тілесного покарання з боку окупантів, однак факти безпідставного насильства фігурують у спогадах доволі рідко. Зокрема, Н.Ф. Орєшкова (1923 р.н., с. Ботієве) розповідає про вбивство румуном дівчини у с. Богданівка: «С девчонкой стал встречаться парень, это, румын. Ну, пригласил ее на Новый год (неразб.) в клуб, где там. Она не согласилась, и он ее застрелил прямо в хате»44. Траплялося, що подібні вчинки каралися німецьким командуванням. Наприклад, житель с. Преслав О.Ф. Малєв (1922 р.н.) розповідає про випадок, коли декількох румунських військових прилюдно покарали побиттям за спробу зґвалтування місцевої жительки ${ }^{45}$.

\footnotetext{
32 Ibid. C. 200.

33 Мільчев B.І. Між двох диктатур: Першоджерела про витоки переселенської активності болгарського населення Таврії в роки Другої Світової війни. Наукові праці історичного факультету Запорізького національного університету. Запоріжжя, 2016. Вип. 46. С. 227.

34 Беркгоф Карел. Жнива розпачу. Життя і смерть в Україні під нацистською владою. Київ: Критика, 2011. С. 137; Запорізький рахунок Великій війні... С. 172.

35 Фонограма спогадів Малєва Івана Андрійовича (1937 р.н.), записаних у селі Райнівка Приморського району Запорізької області у 2018 р.

36 Розпорядження орткомендатури м. Бердянськ про заборону повернення колишнім власникам майна, яке було конфісковано радянською владою Держсавний архів Запорізької області. Ф.Р3051. Оп. 1. Спр. 4. Арк. 23.

37 Беркгоф Карел. Жнива розпачу... С. 138-140.

38 Іріоглу Ю. Друга світова війна... С. 180.

39 Усна історія Степової України... С. 37-38.

40 Ibid. C. 99.

41 Ibid. C. 116-117.

42 Ibid. C. 332.

43 Фонограма спогадів Орєшкової Надії Федорівни (1923 р.н.), записаних у селі Ботієве Приазовського району Запорізької області 03.09.2002 p.

44 Ibidem.

45 Усна історія Степової України... С. 99.
} 
Немає підстав вважати, що відносно м’яке ставлення з боку окупантів до жителів болгарських сіл було зумовлене їх національністю. Як відмічають респонденти А.Т. Кулова (1925 р.н., с. Ботієве) та М.П. Тодоров (1920 р.н., с. Ботієве), ніякої різниці у ставленні окупантів до болгар, українців і росіян, що проживали у селі, вони не помітили ${ }^{46}$.

Окремо слід згадати про вимушений колабораціонізм, і болгарські села Приазов'я у цьому плані не стали винятком. За словами більшості респондентів с. Преслав, які торкаються даної теми, місцеві поліцаї, як правило, намагалися не завдавати шкоди односельцям ${ }^{47}$. На думку дослідника Ю.О. Іріоглу, причиною подібного ставлення могли бути тісні родинні зв'язки, що зберігалися у болгарському селі досліджуваного періоду48. Негативні відгуки жителів с. Преслав про поліцаїв зустрічаються дуже рідко, і приклади «поганих» поліцаїв згадуються як виняток. Наприклад, А.І. Фуклєв (1922 р.н.) згадує про побої, які зазнавали він сам та його односельці з боку поліцая ${ }^{49}$. Проте ситуація в інших селах могла відрізнятися. Респондент М.І. Чернишев (1939 р.н., с. Райнівка) розповідає про випадок у болгарському селі Федорівка, коли поліцаї вбили дитину, допитуючи матір (тітку респондента) ${ }^{50}$.

Проте, навіть незважаючи на відносно м'яке ставлення з боку окремих представників німецьких і румунських військ, саме життя місцевих селян в умовах окупації залишалося у небезпеці. У низці наказів і розпоряджень окупаційної адміністрації, які стосуються, у тому числі, й місцевих болгарських сіл, ми нерідко зустрічаємо погрозу стратою за виконання певних дій, що потенційно могли становити загрозу для німецької влади. Так, у вже згаданому наказі від 10 січня 1942 р. під страхом смертної кари вимагалося здати усю зброю та боєприпаси, які знаходилися у місцевого населення51. В іншому наказі начальника Ногайського району М. Полункіна старості с. Інзовки П. Мільчеву від 24 січня 1942 р. населення під загрозою розстрілу зобов'язувалося негайно здати в районну управу усі радіоприймачі та приладдя до них, електрообладнання, «що не використовується, як зайве, або заборонене», i навіть «увесь папір, який розтягнено з редакції, кооперативів та установ». Причому зазначалося, що особи, які не здадуть вищевказаних речей, «будуть розстріляні не лише самі, але і їх сім'ї» 52 .

На території Запорізької області за роки окупації було розстріляно велику кількість мирних жителів, у числі яких були й болгари. На сторінках «Книги скорботи України», що містить списки жертв окупації, зустрічаємо чимало прізвищ болгар, жителів сіл Богданівка, Ботієве, Велика Тернівка, Вячеславка, Ганнівка, Гюнівка,

\footnotetext{
46 Фонограма спогадів Кулової Антоніни Терентіївни (1925 р.н.), записаних у селі Ботієве Приазовського району Запорізької області 06.09.2002 р.; Фонограма спогадів Тодорова Миколи Петровича (1920 р.н.), записаних у селі Ботієве Приазовського району Запорізької області 02.09.2002 p.

47 Усна історія Степової України... С. 81-82, 88, 125, 383.

48 Іріоглу Ю. Вказ. пр. С. 181.

49 Усна історія Степової України... С. 117.

50 Фонограма спогадів Чернишева Миколи Івановича (1939 р.н.), записаних у селі Райнівка Приморського району Запорізької області у 2018 р.

51 Наказ начальника Ногайського району М. Полункіна старості с. Інзовка П. Мільчеву відносно заходів, які необхідно вжити. Державний архів Запорізької області. Ф.Р-3051. Оп. 1. Спр. 2. Арк. 108.

52 Наказ начальника Ногайського району М. Полункіна старості с. Інзовка П. Мільчеву щодо необхідності негайної здачі населенням радіоприймачів та паперу, та про міри покарання за його невиконання. Державний архів Запорізької області. Ф. Р.-3051. Оп. 1. Спр. 2. Арк. 122.
} 
Зеленівка, Інзівка, Коларівка (нині - Болгарка), Мануйлівка, Маринівка, Надеждине, Петрівка, Преслав, Радолівка, Райнівка, Степанівка Друга, Строганівка53. Свідчення про болгар, розстріляних окупаційною владою, містять і архівні документи. Зокрема зі списку мешканців с. Преслав, страчених у період німецько-фашистської окупації, датованого 18 жовтня 1943 р., ми можемо дізнатися, що у Приморську у грудні 1941 р. було розстріляно жителя с. Преслав П.В. Балєва (1891 р.н.), а у січні 1942 р. - М.М. Чекменджи (1907 р.н.). Ще два жителя села, П.І. Єнчев (1911 р.н.) і М.М. Гогунський (1913 р.н.), у липні 1943 р. були заарештовані та відправлені до бердянської в'язниці, де і загинули ${ }^{54}$.

На території області поширювався рух опору, створювалися різноманітні підпільні організації. Жителі болгарських сіл також брали участь у боротьбі проти окупантів. Зокрема у Райнівці існувала підпільна група, керівником якої був Дмитро Миронович Мячин. Окрім нього до групи входили також П. Мячин, К. Бєлєв, А. Жавжаров, В. Янаков, Ф. Янаков та інші. Кожен з вищевказаних членів групи мав залучити до роботи ще декількох осіб, яких не повинні були знати інші члени групи. Повного складу організації не знав навіть її керівник, який підтримував зв’язок з підпільним райкомом партії. Група збирала та передавала інформацію про переміщення та чисельний склад фашистських військ, їх боєздатність і слабкі місця, вела агітаційну роботу (здебільшого усну, щоб не залишати слідів), здійснювала диверсії тощо. Завдяки умілому керівництву та конспірації група не була виявлена окупантами 55 .

У с. Коларівка та на ст. Єлизаветівка діяла ще одна підпільна група, організована I. Сивороткою. До ії̈ складу входили і болгари: П.С. Радєв, П.Д. Русев, В.Д. Паскалов та В.І. Христова, які приймали активну участь у діяльності групи. Члени організації займалися тим, що переписували від руки й поширювали антинімецькі листівки, а також зривали відправку свиней і худоби зі ст. Єлизаветівка. Напередодні відступу німецьких військ члени групи знищили бензин, спеціально завезений німцями для підпалу хлібних складів, заховали та зберегли від вивозу до Німеччини обладнання Коларівської МТС. Група також не була викрита окупантами ${ }^{56}$.

У Преславі теж діяла підпільна організація, що займалася поширенням листівок, збирала одяг для радянських військовополонених, а також допомагала їм тікати 3 полону. Проте серед ії членів (принаймні, найбільш відомих) практично не зустрічається болгарських прізвищ. На жаль, організацію було розкрито, а їі учасників розстріляно ${ }^{57}$.

Вивезення молоді на примусову роботу до Німеччини, що практикувалося окупантами на завойованій території, у тому числі й у болгарських селах Північного Приазов'я, стало ще одним фактором, що посилював негативне ставлення місцевого населення до німецької влади. Молодь з болгарських сіл під конвоєм доставляли спочатку на пункт збору, а потім - на залізничну станцію у м. Мелітополь чи у

\footnotetext{
53 Книга скорботи України. Запорізька область / головна ред. кол.: І.О. Герасимов (керівник) та ін., обласна ред. кол.: А.В. Казачук (керівник) та ін. Запоріжжя: Обласне пошуково-видавниче агентство «Книга пам'яті України», 2000. С. 414-417, 429-441, 493.

54 Запорізький архів. Народна війна... С. 413-414.

55 Жавжаров Л.В. Указ. раб. С. 39-41; Запорізький архів. Народна війна... С. 415-417.

56 Запорізький архів. Народна війна... С. 221-223.

57 Ibid. C. 413-414; История городов и сёл Украинской ССР: Запорожская область. Киев: 1981.

С. 608; Усна історія Степової України... С. 201, 249-251.
} 
м. Бердянськ. Майбутніх остарбайтерів транспортували до Німеччини у вагонах, призначених для худоби, причому ці вагони зазвичай були переповненими ${ }^{58}$.

Становище болгар-остарбайтерів мало відрізнялося від становища інших робітників з України. Дослідники відзначають, що нацисти не тільки не виділяли українських болгар в окрему групу, а й взагалі не ділили робітників з території СРСР за етнічною ознакою59. Вихідці з болгарських сіл Приазов'я працювали як на промислових підприємствах, так і в сільському господарстві, а також в якості хатньої прислуги. Незалежно від галузі, в якій працювали «робітники зі Сходу», умови їх роботи та проживання були набагато гіршими, ніж їх змальовувала німецька пропаганда. Робітники промислових підприємств утримувалися під охороною у спеціальних таборах, причому виходити за межі табору самостійно їм не дозволялося, на роботу та з роботи їх водили під конвоєм. «На работу строем ведут, в семь, и до вечера. И обратно ведут строем, ворота открыли, зашли, закрыли ворота. (...) забор кругом высокий, наверху колючая проволока и под напряжением, охрана стоит с автоматами» - розповідає В.Г. Мілєв (1926 р.н., с. Преслав)60. Проживання у таборах під охороною відмічають також респонденти 0.0.Кочкова (1923 р.н.) $)^{61}$ та М.О. Атанасова (1925 р.н.) ${ }^{62}$.

Низка респондентів, у тому числі А.І.Фуклєв (1922 р.н.) ${ }^{63}$, О.О.Кочкова (1923 р.н.)64, М.О. Атанасова (1925 р.н.)65, відмічають вкрай погане харчування остарбайтерів, задіяних у промисловості. Певним винятком на фоні цих свідчень виглядають спогади М.I. Гінової (1924 р.н.). Власники заводу, на якому вона працювала, добре ставилися до своїх робітників-остарбайтерів і намагалися створити їм належні умови 66.

Умови проживання й харчування остарбайтерів, задіяних у сільському господарстві, були різними та залежали від господарів. Жителі с. Ботієве, колишні остарбайтери М.Ф. Волчанова (1924 р.н.) ${ }^{67}$ та М.Я. Гайдаржи (1925 р.н.) ${ }^{68}$ пригадують, що харчування на фермах, де вони знаходилися, було поганим, однак в умовах сільського господарства у робітників була можливість потайки підхарчовуватися тими продуктами, що вирощувалися на фермі. А М.М. Кулова (1919 р.н., с. Ботієве), зі слів своєї сестри, яка працювала у сільському господарстві, зазначає, що харчування у них було дуже добрим ${ }^{69}$.

Серед респондентів-болгар є згадки про втечі. Так, наприклад, тікати доводилося

\footnotetext{
58 Жавжаров Л.В. Указ. раб. С. 38; Усна історія Степової України... С. 221.

59 Пастушенко Т.В. Будні українських остарбайтерів: боротьба за виживання (на матеріалах спогадів колишніх примусових робітників). Український історичний журнал. 2005. № 6. С. 172.

60 Усна історія Степової України... С. 222.

61 Ibid. C. 129.

62 Ibid. C. 141.

63 Ibid. C. 118.

64 Ibid. C. 128.

65 Ibid. C. 141.

66 Ibid. C. 97.

67 Фонограма спогадів Волчанової Марії Федорівни (1924 р.н.), записаних у селі Ботієве Приазовського району Запорізької області 03.09.2002 p.

68 По ту сторону войны. Книга памяти жертв нацистских преследований в годы Второй мировой войны / сост.: Н. Михайлов, Н. Кузьменко и др. Запорожье: РА «Тандем-У», 2005. С. 121-123.

69 Фонограма спогадів Кулової Марії Михайлівни (1919 р.н.), записаних у селі Ботієве Приазовського району Запорізької області 02.09.2002 p.
} 
О.Ф. Малєву (1922 р.н.)70 та В.Г. Мілєву (1926 р.н.)71. Утікачів ловили та повертали на старе місце роботи ${ }^{72}$ або направляли на нове ${ }^{73}$. Стосовно покарання для втікачів пригадує лише В.Г. Мілєв (1926 р.н.): «[Наказали...]. Не сильно, это хорошо, что шеф потребовал, шоб отпустить, а то отлупили гумами, и отвезли в лагерь опять» 74 .

0.0. Кочкова (1923 р.н.) повідомляє про випадки страйків у таборі, які остарбайтери іноді влаштовували через погане харчування. Крім того, респондентка описує випадок, коли робітники, які збиралися втекти, убили конвоїра, що супроводжував їх на шляху від заводу до табору. За свідченням респондентки, інші остарбайтери не тільки не зазнали ніякого покарання, а навіть їх становище дещо полегшилося, оскільки тепер на роботу та з роботи вони почали ходити без конвою: «Какой-то фриц провожает нас до барака, куда, куда убежишь. (...) Кто будет бежать, ну решились, убьют этого немца (...) и вот ждали, ждали пока все соберутся, и я не могу точно сказать, как прошёл, с чем, как, гакнули и убили, чи камнем чи чем, чи он, пристрелили его. Никто ничего не сделали, открыли двери и больше не замыкали, утром себе идешь от барака до завода» 75.

Хоча офіційно пропагувалося зверхнє ставлення до «робітників зі Сходу», ставлення німецького населення до остарбайтерів було різним - тут велику роль грав «людський фактор». Багато респондентів пригадують випадки, коли німці співчували остарбайтерам і допомагали їм. Так, А.І. Фуклєв (1922 р.н.) ${ }^{76}$, В.Г. Мілєв (1926 р.н.) 77 , М.Ф. Волчанова (1924 р.н., с. Ботієве) ${ }^{78}$ розповідають про те, як німці допомагали харчами остарбайтерам. Про добре ставлення з боку окремих господарів до остарбайтерів повідомляють також М.М. Кулова (1919 р.н., с. Ботєве) ${ }^{79}$ та М.І. Гінова (1924 р.н., с. Преслав) 80.

Остарбайтери мали право отримувати від родичів листи та посилки, але самі могли надсилати лише поштові картки двічі на місяць. Уся кореспонденція перевірялася81, «Что там плохо или что, не писали! Мы сами боялись!» - розповідає М.І. Гінова (1924 р.н.) ${ }^{82}$.

Отже, як ми переконалися, й у рідному селі під час окупації, і на примусових роботах у Німеччині, болгари Північного Приазов'я не мали помітних преференцій за національною ознакою порівняно з іншими жителями регіону. Але все ж була одна обставина, за якою болгари відрізнялися - можливість встановлення зв'язку з історичною батьківщиною з метою пошуку захисту у скрутних обставинах. Щоправда, використання цієї можливості не набуло великого поширення.

В історичній літературі $\epsilon$ відомим фактом спроба секретаря болгарського консульства у м. Кельн Георгія Шишкова допомогти болгарам - вихідцям з Приазов'я,

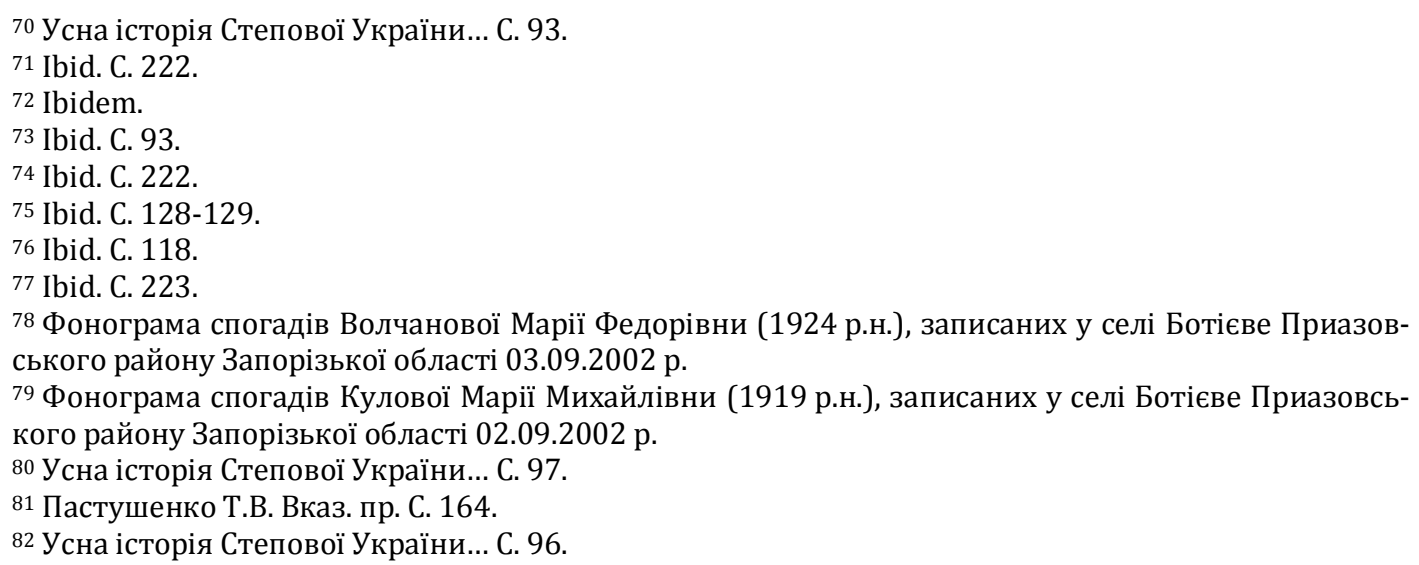


що знаходилась у той час на примусових роботах у Німеччині. Він, зокрема, клопотав перед головною дирекцією Німецького трудового фронту про їх звільнення та переправлення до Болгарії. Список, складений Шишковим, налічував понад 300 осіб. Проте це клопотання залишилося без задоволення на тій підставі, що таврійські болгари-остарбайтери не були громадянами Болгарії, а отже не підпадали під захист трудових угод між Болгарією та Німеччиною. 3 боку болгарського уряду дана ініціатива також не отримала належного сприяння унаслідок побоювань, що таврійська молодь після отримання болгарського громадянства може не залишитися лояльною до Болгарії83.

Свідчення про діяльність Г. Шишкова зустрічаються й у спогадах колишніх остарбайтерів-болгар. Зокрема житель с. Преслав О.Ф. Малєв (1922 р.н.), який деякий час працював у Кельні, розповідає, що болгарський консул неодноразово відвідував їх табір, і навіть допомагав лікувати двоюрідну сестру респондента ${ }^{84}$. А житель с. Інзівки І.З. Вапіров (1912 р.н.) згадує, що Георгій Шишков допоміг йому встановити переписку з односельцем Мішо Хаджийським, який у той час знаходився у Болгарії85.

Частина жителів окупованих болгарських сіл Північного Приазов'я в умовах утисків німецької влади також пов'язувала з історичною батьківщиною надії на допомогу та порятунок. У квітні 1942 р. за ініціативою письменника Мішо Хаджийського (уродженця села Інзівки) був написаний лист до болгарського царя Бориса III з проханням дозволити таврійським болгарам переселитися на історичну батьківщину. Лист підписав також староста Інзівки Петро Мільчев і ще 16 осіб (здебільшого представники інтелігенції). Отримавши дозвіл німецької комендатури, М. Хаджийський виїхав до Болгарії. По дорозі письменник відвідав болгарське посольство у Бухаресті, через яке і передав адресований Борису III лист. У Болгарії М. Хаджийський розгорнув діяльність, спрямовану на ознайомлення болгарської громадськості із долею болгар України. Зрештою болгарський уряд домовився 3 Німеччиною про переселення 2500 етнічних болгар з України до Болгарії. Усього у період з листопада 1943 р. по осінь 1944 р. до Болгарії прибуло декілька партій переселенців. Вони були розселені здебільшого у Південній Добруджі ${ }^{86}$, яку Болгарія повернула собі у 1940 р. згідно з Крайовською угодою.

Точне число переселенців встановити не вдалося: за різними даними їх число коливається від 1228 до 1900 осіб87. Слід зазначити, що у 1939 р., згідно з переписом населення, у селах Запорізької області мешкало 34237 болгар ${ }^{88}$. Тобто, число переселенців становило менше 6\% від усього сільського болгарського населення

\footnotetext{
83 Чукова Р. Обществената дейност на Мишо (Михаил) Хаджийски: Историографски ракурси и публична памет. Україна і Болгарія в історії Європи: збірник наукових праць. Київ: Ін-т історії України НАН України, 2019. С. 154.

84 Усна історія Степової України... С. 93.

85 Паскалов Л. Таврійські історії... С. 205.

86 Гочев Я. Преселението на Таврийските българи: бягство от смъртта и терора на съветската власт. URL: https://www.faktor.bg/bg/articles/politika/na-vseki-kilometar/preselenieto-natavriyskite-balgari-byagstvo-ot-smartta-i-terora-na-savetskata-vlast-50010 (дата звернення 30.03.2020); Мільчев В.І. Між двох диктатур... С. 227-228.

87 Гочев Я. Преселението на Таврийските българи...

88 Станчев М.Г. Болгары в Российской империи, СССР, странах Балтии и СНГ. Т. 1: Статистический сборник (1711-2006). София: Академическое издательство имени проф. Марина Дринова, 2009. C. 223.
} 
Запорізької області. До того ж у числі переселенців були також болгари з інших регіонів України - Бессарабії, Криму, Кіровоградщини та Миколаївщини ${ }^{89}$.

Подальша доля переселенців сумна. За вимогою Сталіна у 1945 р. переселенці були примусово повернені до СРСР та поселені на території Таджикистану. Уникнути репатріації вдалося дуже невеликій кількості приазовських болгар ${ }^{90}$.

Один з ініціаторів переселення, староста с. Інзівки Петро Мільчев, на закритому судовому засіданні у м. Слівен був засуджений військовим трибуналом 37-ї армії до 10 років ув'язнення. Разом з ним за «співробітництво з окупантами» й «антирадянську агітацію» на той же термін було засуджено ще 6 осіб, уродженців с. Інзівки 91. Вчителі Василь Малчев і Георгій Соломонов, що також поставили свої підписи під листом до Бориса III, теж були засуджені на значні терміни ув'язнення, а письменник Мішо Хаджийський під час повторного арешту покінчив життя самогубством $^{92}$.

Визволення більшості населених пунктів Запорізької області від німецької окупації відбувалося у вересні-жовтні 1943 р.93, болгарські села було визволено 1820 вересня 1943 року військами 28-ї армії Південного фронту94. Проте із завершенням окупації становище болгарського села не покращилось миттєво. Війна призвела не лише до людських, але й до значних матеріальних втрат: у ході бойових дій було зруйновано чимало колгоспних будівель, доріг, мостів, шкіл і лікарень, постраждало й особисте майно селян.

Великої шкоди господарству відступаючі німецькі війська завдавали навмисне: підпалювали будівлі та сільськогосподарську продукцію, вилучали у селян худобу. Респонденти згадують: «Они (німці - Aвт.) когда отступали, палили скирды все колхозные. (...) В амбарах хлеб побрызгали бензином, подпалили и уехали дальше. Скот выгоняли в степи. Куда их забирали? (...) Страшно было» (Мінкова М.Ф., 1927 р.н., народилася у Райнівці) ${ }^{95}$, «Запалили мельницу одну, запалили другую мельницу, от! Запалили маслобойку, от такое что надо было, они все попалили! И за кони, и поехали! (...) негде и крупы смолоть» (Стояновська 3.Д., 1922 р.н., с. Преслав) ${ }^{96}$, «Мельница была у Стогановке (...) Запалили мельницу. А в Ботеве сорвали мост, на Строгановку нельзя уже идти» (Орєшкова Н.Ф., 1923 р.н.,

\footnotetext{
${ }^{89}$ Митков В.В. Голгофа болгар Таврии: анатомия репрессий (1920-е - 1940-е годы). Запорожье: Тандем-У, 2009. С. 122.

90 Гочев Я. Зловещата 1945 г. - БКП праща на смърт в СССР по искане на Сталин таврийските българи. URL: https://www.faktor.bg/bg/articles/ politika/na-vseki-kilometar/194554070/27 (дата звернення 30.03.2020); Митков В.В. Голгофа болгар Таврии... С. 123-124; Мільчев В.І. Між двох диктатур... С. 228.

91 Вирок військового трибуналу 37-ї армії від 6-7 липня 1945 р. у справі з обвинувачення громадян СРСР Клименко Олени Олександрівни, Мільчева Петра Дмитровича, Мільчевського Петра Андрійовича, Терзієва Івана Дмитровича, Буюклійського Дмитра Олексійовича, Мільчевського Івана Георгійовича. Галузевий державний архів СБ України, м. Запоріжжя Справа №19886-П. Т. 1. Арк. 291-297.

92 Гочев Я. Зловещата 1945 г...; Митков В.В. Голгофа болгар Таврии... С. 123-124; Мільчев В.І. Між двох диктатур... С. 228.

93 Запорожская область в годы Великой Отечественной войны (1941-1945). Сборник документов. Запорожье: Запорожское книжно-газетное издательство, 1959. С. 357.

94 Журнал боевых действий войск южного фронта. Бои за освобождение Донбасса и выход на рубеж p. Молочная. Сентябрь 1943 г. Центральный архив Министерства обороны Российской Федерации. Ф. 64. Оп. 505. Д. 205. С. 98-108. URL: https://pamyat-naroda.ru/documents/view/?id=110110218 95 Усна історія Степової України... С. 283-284.

96 Ibid. C. 112.
} 
с. Ботієве)97, «А тогда они уже отъезжали, подпалили амбар (...) пшеницу подпалили они...» (Чернишева В.А., 1928 р.н., с. Райнівка) ${ }^{98}$.

Після звільнення території від німецько-фашистської окупації було складено величезну кількість актів про заподіяні збитки. Багато таких документів стосувалися й болгарських сіл. Так, наприклад, в Акті від 28 вересня 1943 р. було відзначено, що у членів колгоспу «КІМ» (с. Петрівка) окупантами було спалено 1 будинок повністю і ще 5 частково постраждали від вогню (2 на 40\%, 3 на 30\%), було вилучено й убито 186 голів великої рогатої худоби, 413 овець, 53 свині та 1259 птахів. Всього членам колгоспу було заподіяно шкоди на суму 14809210 крб.99 В одному 3 актів по с. Радолівка від 19 березня 1944 р. було вказано, що у мешканця села Тигова 0. німцями було вилучено 2 корови, 2 вівці, 40 гусей, 8 качок, 25 курей, 600 яєць, 1640 літрів молока та 400 кг озимої пшениці. Всього його родині було заподіяно шкоди на суму 91588 крб. 100

На жаль, під час відступу німецьких військ не обійшлося й без людських жертв серед мирного населення. Зокрема, в Акті від 4 жовтня 1943 р., складеному комісією з розслідування злочинів фашистських окупантів та їх посібників, повідомляється про розстріл групи мешканців с. Інзовка з 8 чоловік, а саме: Хаджийського В.І., Хаджийського І.С., Греблєва П.А., Гердова І.А., Мільчева А.П., Парапанова А.П., Гедікова С.П. та Дойнова В.I.101.

Таким чином, у результаті дослідження було виявлено, що попри статус Болгарії як союзника Німеччини у Другій світовій війні болгари Північного Приазов'я не мали помітних преференцій за національною ознакою порівняно з іншими жителями регіону. Болгарське населення у повній мірі зазнало на собі економічні утиски, фізичні покарання, страти, а також примусове вивезення молоді до Німеччини в якості робочої сили. Місцеві болгари брали участь і у русі опору, зокрема входили до складу підпільних груп у Райнівці та Коларівці. Становище болгаростарбайтерів також мало відрізнялося від становища інших робітників з України.

Єдиною особливістю у становищі приазовських болгар, порівняно з рештою населення регіону, стала можливість звернення до історичної батьківщини у пошуках захисту та допомоги, яка, однак, не набула значного поширення. Зокрема, ми маємо свідчення про факти допомоги таврійським болгарам-остарбайтерам з боку секретаря болгарського консульства у м. Кельн Г. Шишкова. Іншим виявом використання такої можливості стала спроба переселення деякої кількості таврійських болгар на історичну батьківщину, однак вже у 1945 р. за вимогою радянського уряду переселенці були повернені до СРСР.

\footnotetext{
97 Фонограма спогадів Орєшкової Надії Федорівни (1923 р.н.), записаних у селі Ботієве Приазовського району Запорізької області 03.09.2002 p.

98 Фонограма спогадів Чернишевої Валентини Аркадіївни (1928 р.н.), записаних у селі Райнівка Приморського району Запорізької області у 2018 р.

99 Списки і акти громадян, яким нанесені збитки німцями. (Виконавчий комітет Петрівської сільської Ради депутатів трудящих. Село Петрівка Приморського району, Запорізької області). Державний архів Запорізької області. Ф. Р-3518. Оп. 1. Спр. 1. Арк. 2.

100 Акти про принесений збиток громадянам німецькими військами. (Виконавчий комітет Радолівської Сільської ради депутатів трудящих с. Радолівка, Приморського району, Запорізької області. 1944-1954рр.). Державний архів Запорізької області. Ф. Р-4667. Оп. 1. Спр. 4. Арк. 27.

101 Акт, складений комісією з розслідування злочинів фашистських окупантів та їх посібників, за фактом розстрілу групи мешканців с. Інзовка. Державний архів Запорізької області. Ф.Р-2045. Оп. 1. Спр. 1. Арк. 29.
} 


\section{REFERENCES}

Berkhoff, K. (2011). Zhnyva rozpachu. Zhyttia i smert v Ukraini pid natsystskoiu vladoiu [Harvest of Despair: Life and Death in Ukraine Under Nazi Rule]. Kyiv: Krytyka [in Ukrainian].

Chukova, R. (2019). Obshtestvenata deynost na Misho (Mihail) Hadzhiyski: Istoriografski rakursi i publichna pamet [Misho (Mihail) Hadjiiski's Public Activity: Historiographical Perspectives and Public Memory]. Ukraina i Bolhariia v istorii Yevropy: zbirnyk naukovykh prats, (pp. 148-161). KyivSofiia [in Bulgarian].

Dobrev, V. D. (2009). Chushmelii [Chushmelii]. Melitopol' - Velyko Tyrnovo [in Ukrainian].

Gochev, Y. (2015, July 13). Preselenieto na Tavriyskite balgari: byagstvo ot smartta i terora na savetskata vlast [The Migration of the Taurida Bulgarians: Escape from the Death and Terror of the Soviet Power]. Faktor.bg. Retrieved from https://www.faktor.bg/bg/articles/politika/na-vsekikilometar/preselenieto-na-tavriyskite-balgari-byagstvo-ot-smartta-i-terora-na-savetskata-vlast50010 [in Bulgarian].

Gochev, Y. (2015, September 4). Zloveshtata 1945 g. - BKP prashta na smart v SSSR po iskane na Stalin tavriyskite balgari [The ominous 1945 - the Bulgarian Communist Party sends Taurian Bulgarians to their deaths in the USSR at Stalin's request]. Faktor.bg. Retrieved from https://www.faktor.bg/bg/articles/politika/na-vseki-kilometar/194554070/27 [in Bulgarian].

Iriohlu, Y. (2009). Druha svitova viina v usnykh istoriiakh bolhar Pivnichnoho Pryazovia [World War II in the oral histories of the Bulgarians of the Northern Priazovye]. Balgarite $v$ Severnoto Prichernomorie. Izsledvania i materiali. Vol. 10, pp. 179-186. Odesa - Veliko Tarnovo [in Ukrainian].

Milchev, V.I. (2016). Mizh dvokh dyktatur: Pershodzherela pro vytoky pereselenskoi aktyvnosti bolharskoho naselennia Tavrii v roky Druhoi Svitovoi viiny [Between two dictatorships: Primary sources on the origins of the resettlement activity of the Bulgarian population of Tavria during the Second World War]. Naukovi pratsi istorychnoho fakultetu Zaporizkoho natsionalnoho universytetu, (46), 226-243 [in Ukrainian].

Mitkov, V.V. (2009). Golgofa bolgar Tavrii: anatomiia repressii (1920-e - 1940-e gody) [Calvary of the Bulgarians of Tavria: the anatomy of repression (1920s - 1940s)]. Zaporozhe: Tandem-U. [in Russian].

Nozdrina, L.F. (2012). Bolgary Priazovia uchastniki istoricheskikh sobytii XX veka [The Bulgarians of Priazovye - participants in the historical events of the twentieth century]. Abstracts of Papers: IV Pryazovskyi bolharystychnyi seminar (pp. 90-100). Melitopol - Veliko Tyrnovo [in Russian].

Pastushenko, T.V. (2005). Budni ukrainskykh ostarbaiteriv: borotba za vyzhyvannia (na materialakh spohadiv kolyshnikh prymusovykh robitnykiv) [Everyday life of Ukrainian ostarbeiters: the struggle for survival (based on the memoirs of former forced laborers)]. Ukrainskyi istorychnyi zhurnal, 6, 160-175 [in Ukrainian].

Shaikan, V. (2010). Povsiakdennia ukraintsiv u roky nimetskoi okupatsii. 1941-1944 [Everyday life of Ukrainians during the years of German occupation. 1941-1944]. Kyiv [in Ukrainian].

Tron'ko, P.T. (1981). Istoriia gorodov i sel Ukrainskoi SSR: Zaporozhskaia oblast [History of cities and villages of the Ukrainian SSR: Zaporozhye region]. Kyiv [in Russian].

Turchenko, F.H., Moroko, V.M., Shteinle, O.F. \& Orlianskyi, V.S. (2013). Zaporizkyi rakhunok Velykii viini. 1939-1945 [Zaporizhzhia account of the Great War. 1939-1945]. Zaporizhzhia: Prosvita [in Ukrainian].

Zhavzharov, L.V. (2011). Rainovka: istoriia i sudby [Rainovka: history and fate]. Melitopol': Izdatelskii dom MGT [in Russian].

\section{Mariya Pacheva}

(Zaporizhzhia National University, Zaporizhzhia, Ukraine)

e-mail: pacheva.mariya.18@gmail.com

ORCID: https://orcid.org/0000-0003-3635-4508

\section{Bulgarian Villages of North Azov Sea Region in 1941-1943: German Occupation in Ethnic Dimension}

The goal of the scientific study is to identify the peculiarities of the situation in Bulgarian ethnic minority under the conditions of the Fascist occupation regime. In other words, to determine whether the fact of Bulgaria's allied status with Germany in World War II affected the 
situation with a Bulgarian population in the South of Ukraine. Though there are many works in the national historiography devoted to the study of the situation of the rural population of Ukraine during World War II, its analysis in terms of separate ethnic groups has not been given enough attention. The territorial framework of the study is localized in the North Azov Sea region since there was the largest area of compact Bulgarian settlement on the territories included in the Reich Commissariat Ukraine (Bulgarian villages in Bessarabia were known to be located in Romanian occupation zone).

It has been found out that both in their native villages during the occupation and in forced labor in Germany, Bulgarians of the North Azov Sea region did not have any marked preferences on national grounds compared to other residents of the region. Bulgarian population had been fully subjected to economic oppression, physical punishment, executions, and the forced deportation of young people to Germany as a labor force. Local Bulgarians also took part in the resistance movement. In particular, they were members of underground groups in Rainivka and Kolarivka. The status of Bulgarian Ostarbeiters also differed little from that of other Ukrainian workers.

The only circumstance that distinguished the status of Bulgarians from the rest of the population of the South of Ukraine was the possibility of establishing contact with the historical homeland in order to seek protection and help. However, the use of that opportunity had not become widespread. In particular, we have evidence of the facts of assistance to the Taurian Bulgarians, the natives of the Azov region, who performed forced labor in Germany at that time, by Georgi Shishkov, the Secretary of the Bulgarian Consulate in Cologne.

Some residents of the occupied Bulgarian villages of the North Azov Sea region, oppressed by German rule, also attributed the hopes of salvation to the historical homeland. In April 1942, a group of residents of the village Inzivka (mostly the representatives of the intelligentsia) wrote a letter to Tsar Boris III of Bulgaria with a request to allow Taurian Bulgarians to resettle to their historical homeland. Eventually, the Bulgarian government agreed with Germany to resettle 2,500 ethnic Bulgarians from Ukraine to Bulgaria. In the period from November 1943 to the autumn of 1944, several parties of immigrants arrived in Bulgaria. However, in 1945, at Stalin's request, the settlers were returned to the USSR, and only a few of them managed to avoid forced repatriation. The initiators of the resettlement got various terms of imprisonment for cooperation with the occupiers and anti-Soviet agitation.

Keywords: Taurian Bulgarians, North Azov Sea region, World War II, repatriation 